\title{
Surrealisme dalam Arsitektur: Penerapan Inkuiri Metafisik pada Karya Arsitektur Kontemporer Yoka Sara
}

\author{
Dea Aulia Widyaevan \\ Desain Interior Universitas Telkom \\ Gedung Sebatik Jl. Telekomunikasi Terusan Buah Batu Indonesia 40257 Bandung Indonesia \\ widyaevan@gmail.com
}

\begin{abstract}
Pengejawantahan konsep intangible pada Arsitektur di Indonesia, masih sangat minim. Padahal, jika menilik arsitektur vernakular, semua konsepnya berbasis filsafati yang menaungi aspek bukan fisikal. Karya arsitek Bali, Yoka Sara, berusaha mengedepankan filosofi ruang berbasis pengetahuan lokal. Pada setiap proses kreatifnya, Yoka Sara berpijak pada indigineous knowledge yang fokus pada faktor yang sifatnya subconsious. Ia terpacu untuk memunculkan perbendaharaan pra-imaji (tidak disadari), imaji abstrak dan imaji konkret (disadari) yang secara holistik dirangkum dalam perolehan imaji-memori yang jelas dapat memberi kemampuan untuk dapat menghayati secara detail maupun keseluruhan melalui pengembangan indra dan perasaan yang selama ini terabaikan. Yoka Sara, melalui pendekatan berarsitekturnya, mencoba mengintegrasi pengetahuan yang dinamis dengan memandang dunia tidak sebagai kotak yang ada (beings) melainkan sebuah proses bergerak dan menjadi dinamis. Ia menawarkan multiplisitas sebagai cara berpikir tentang realitas yang merupakan esensi dan substrata yang tidak statis, melainkan bersifat dinamis dan tumbuh sebagai rangkaian peristiwa dan proses. Pendekatan ini, mejembatani pengetahuan lokalnya dengan praktek arsitektur kontemporenya. Melalui karyanya, Yoka Sara berusaha memaknai arsitektur sebagai daya ungkap ekspresi dari hasrat yang terpendam menuju akar diri/self.
\end{abstract}

Kata kunci: arsitektur dan kosmologi Bali, surealisme, arsitektur kontemporer.

\section{Surrealism in Architecture : Application of Metaphysical Inquiry to Yoka Sara's Contemporary Architectural Work}

Indonesian vernacular architecture has so many of local wisdom, which based its design on intangible concept. Those intangible concept usually related on its unique cultural philosophy, spiritual, way of life or social value. However, those intangible concepts rarely manifest on Indonesian contemporary architecture which has ambivalent identity. Those new architecture has some biased root from where the style, language or new approach come from. Therefore, this paper tries to seek the one of successful case on adaptation of Indonesian contemporary architecture. The specify design approach that relied on transformation of genius loci into new form, without eliminating its essentials. In this case, one of outstanding Indonesian architect in Bali, Yoka Sara, has unique design approach to recreate the traditional contemporary Balinese. In his creative process, Yoka Sara always relied on his indigenious knowledge, which focused on the subconscious basis. Yoka sara always motivated by pre-image subconscious, abstract image and real image which integrated on his pre-memory image. So, he can contemplate the whole senses and emotion beyond the physical form of spaces. Yoka Sara through his deisgn process, try to integrate the dynamic knowledge. He offered multiplicity as a philosophical thinking about how architecture as a space related to reality that contains the essential, dynamic, fluid event of experiences. This kind of approach has becoming a linked of his genius local knowledge to his modern architecture practice. Through his works, Yoka Sara try to seek the meaning of contemporary architecture as a expression and undisclosed desired regarding his Balinese root identitiy - self.

Keywords: Balinese architecture and cosmology, surrealism, contemporary architecture.

Proses Review : 1 - 18 April 2019, Dinyatakan Lolos: 22 April 2019 


\section{PENDAHULUAN}

Arsitektur, merupakan salah satu bentuk representasi cara manusia bertahan di alam. Manusia membangun shelter, sebuah lingkungan binaan berfunsi sebagai proteksi terhadap kondisi alam geografisnya. Cara manusia ber-arsitektur setiap waktunya berubah, sesuai konsekuensi logis dari peralihan jaman. Serangkaian perubahan tersebut, pada suatu saat dapat mencapai titik jenuh. Salah satu indikasinya adalah, pemikiran barat mengenai paradigma ber-arsitektur sudah mulai jenuh. Hal ini dimulai dari munculnya cara pandang baru, tentang dekonstruksi ala timur. Charles Jenk, dalam bukunya The Architecture of Jumping Universe menawarkan pendekatan kosmogenik, pendekatan sains-kosmologis yang mengacu pada nilai timur. Begitu juga dengan Anthony Vidler dalam essaynya The Architectral of Uncanny, yang menggali aspek surealisme dalam arsitektur. Vidler menggali sisi tersembunyi dan metafisik yang sering di represi oleh masyakarakat modern. Berdasarkan dua pandangan kontemporer ini, kini arsitektr menjadi kian tidak terbatas. Melalui dukungan teknologi dan eksplorasi material baru, bentukan arsitektur juga menjadi lebih abstrak. Hal ini menunjukan bahwa pendekatan rasional yang dulunya menjadi ciri Barat, kini tidak mutlak dilaksanakan. Justru pendekatan intangible yang mengacu pada aspek yang bersifat subtil, psikologis dan spiritual amemiliki kemungkian untuk dieksplor dalam produksi ruang arsitektur. Salah satunya, dalam wilayah yang berkarakter metafisis.

Nilai kosmologis timur, bukanlah hal yang baru di Indonesia. Namun, akibat pengaruh kapitalisme global yang melanda, arsitektur Indonesia seolah terombang ambing dalam penentuan identitasnya. Pengetahuan vernakuler yang tadinya menjadi pandangan hidup, kini seolah menjadi terasing dan tidak terintegrasi baik dengan dunia keseharian. Seolah kemampuan praktis dan teknik menjadi lebih utama dibangdingkan dengan pengetahuan tradisi. Salah satunya, terbukti terwujud dalam fenomena Arsitektur di Bali yang kian hari bentukan ruang arsitekturnya terpisah menjadi praktek keseharian yang bersifat sakral. Konsekuensinya, Indonesia seperti mengalami ,profanisasiee $^{\text {, }}$ ketika suatu wujud objek dan tatanan bangunan hanya berlaku praktis tanpa adanya koneksi dengan sebuah keyakinan atau pandangan hidup kolektif. Misalnya di Bali, prinsip kosmik yang menjadi salah satu arketipal budaya lokal Indonesia menjadi bias ketika dikaitkan dengan produksi ruang yang ,modern ${ }^{\text {ee }}$. Arsitektur tampaknya sudah berhenti menyentuh suasana batin, kedalaman rasa manusianya yang kian terlibas budaya universal.

Bali merupakan salah satu contoh, yang sangat terasa dalam arsitektur mengalami pergulatan lokal dan global. Bali merupakan salah satu tempat, yang masih kuat aroma sakral dan vernakulernya. Pada masa kontemporer ini, ketika kapitalisme dan globalisasi bahkan hedonisme mengeksploitasi Bali maka terjadi ketegangan antara pen- getahuan lokal yang masih kuat dengan tuntutan globalisasi. Melihat kondisi riskan ini, salah satu arsitek Bali yang bernama Yoka Sara memilih sudut pandang unik dalam bernegosiasi dengan konteks. Ia menawarkan hal yang paling otentik dari Bali, yakni pengetahuan metafisika Bali.

\section{METODE PENELITIAN}

“....there is a reason why people keep coming to Bali, although they already see its mountain, sea, beaches, and hill so many times, it always still mesmerizing. People want to kiss supranatural of Bali...it"s not about the physicsal things anymore, but... what is beyond, has reckon their unconsciousness to always come back...” ( Sara, 2011).

Anthony Vidler menyatakan, bahwa gerakan surealis dalam arsitektur adalah bentuk dari pembebasan emosi yang terekspresi pada jaman modern. Surealisme berkutat pada aspek di luar nalar, bawah sadar, mimpi, fantasi dan mitos. Karya arsitektur yang berbasis surealis di barat, mengedep "eankan peleburan batas antara realitas-mimpi (Vidler, 1992:7). Pada buku Warped Space: The Explosion of Space; Architecture and Filmy Imaginary Vidler juga mengatakan, bahwa arsitektur itu sebuah realitas yang seperti film:

"I draw out these questions in the context of early twentieth-century debates over the nature and role of spatial distortion in the montage techniques of film, and in the formal attempts of architects like Le Corbusier to design spaces that will both imply and sustain such movement in practice, precipitated literally by his move to aerial vision in the design of urban and territorial space" (Vidler, 2000:108).

Vidler menggagas, bahwa pada hakikatnya sebuah film dibuat sebagai sesuatu yang tidak nyata dan tidak harus percaya pada realitas yang di dalamnya. Mekanisme film dasarnya sama dengan mekanisme mimpi, ketika realitas mimpi hadir dan tidak untuk dipercayai. Jika begitu, bila arsitektur dianalogikan seperti manusia yang mempunyai dua alam (nyata dan mimpi) maka arsitektur memiliki dua sisi yaitu ruang konkret/imagined atau abstrak/unimagined. Ruang, bisa bersifat fisik dan metafisik. Foucoult juga dalam essainya Of Other Spaces: Utopias and Heteropias (1967) mengidentifikasi adanya sebuah heterotopia, ruang transisi konkret - abstrak seperti pada sebuah cermin. Terjadi amplifikasi ruang, yang menandakan realitas objek terlihat namun tidak konkret.

Bangsa Timur, berkelindan dengan aspek metafisis dalam kehidupan sehari-harinya. Berdasarkan segala aspek budaya Bali, metafisika merupakan suatu upaya untuk mencari hakekat dari kenyataan yang sebenarnya. Menjadi titik tolak local wisdom, acuan tradisi yang membentuk khasanah lokalitas. Hanya saja, Indonesia mulai meninggalkan keyakinan kosmik seperti ini karena sudah tergan- 
tikan oleh agama biner dan budaya baru. Aspek metafisik asli Indonesia, dalam khasanah budaya lokal merupakan hal yang paling direpresi dalam modernitas sekarang. Ini tercermin dari modelnya masyarakat lokal berlomba-lom-

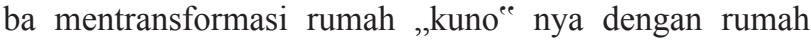
tembok yang kaku dan kotak maupun atap datar bahkan berpagar agar tidak terkesan ,, suwung".

Pada kasus ini, Yoka Sara mengaplikasikan pengetahuan lokalnya yang terepresi. Sisi metafisik sebagai nilai kayakinan lokal, yang ditransformasikan ke bentuk yang lebih modern. Melalui ruang arsitektur, Yoka Sara mencari estetika arsitektur dan menguak esensi ruang dari jarak arsitektur yang dihubungkan dengan sesuatu yang liyan seperti hidup dan mati serta siklus kehidupan. Berdasarkan konteks yang lebih luas, inkuiri metafisika memainkan peranan sebagai katalis dalam saluran kreativitasnya. Oleh sebab itu, proses penciptaan Yoka Sara melibatkan eskpresi pembebasan represinya yang salah satunya dilakukan dengan mendekonstruksi paradigm dan paham arsitektur yang telah ada dengan mengadaptasi konsep kosomgenik.

Menurut Charles Jenks pada bukunya The Architecture of Jumping Universe, pemikiran kosmogenik ini ditawarkan untuk melakukan dekonstruksi yang mengijinkan menembus dan menerobos berbagai wilayah ilmu termasuk kosmologi itu sendiri. Dekonstruksi ini bukan dimaksudkan untuk melupakan masa lalu, tetapi bertujuan untuk membuat suatu inskripsi baru yang melibatkan rasa hormat pada tradisi.

What is the cosmogenic world view? It is the idea that the universe is a single, unfolding self-organizing event, something more like an animal than machine, something radically interconnected and creative, an entity that jumps suddenly to higher levels of organization and delights us as it does so (Jencks, 1997:125).

Menurut pengertian kosmogenik, waktu tidaklah berjalan linier seperti modern sehingga perlu pencarian hal ihwal/ akar dari sebuah kultur lokal. Istilah kosmogenik mengacu pada pengertian proses penciptaan alam semesta, yang saling berkelindan dan berhubungan. Definisi realitas menjadi tumpang tindih dan parallel, sehingga paradigma yang diambil dari basis ilmu sains (teori big bang, relativitas, dsb) diaplikasikan ke dalam paradigma penciptaan ruang dalam Arsitektur. Pemikiran ini kemudian menjadi oposisi dari peradaban Barat, yang masih berjarak dengan aspek "diluar jangkauan nalar" seperti peristiwa kematian atau kepunuhan maupun fenomena spiritual lainnya. Selain itu, Jencks juga merujuk pada budaya kosmik timur yang banyak diterapkan pada arsitektur Jepang kontemporer. Dicontohkannya karya Isuko Hasegawa, yang mempertanyakan ruang transient sebagai unsur inti pada keyakinan zen di Jepang.
Here we touch an essential problem: how is the permanent art of architecture to represent the changing, sometimes ephemeral, nature of reality? Itsuko Hasegawa has discovered one way, with her steely-grey aesthetic of undulating panels.... These waveforms signify connections with nature, what she calls a second-nature that is built. The metallic forms are also particularly sensitive to changes in weather and light, reflecting them as a chameleon mirrors its environment (Jencks, 1997: 136)

Arsitektur yang berorientasi pada konsep kosmos, memiliki tantangan dalam hal metafora bentuk. Melalui bantuan teknologi, konstruksi timur direinkarnasi melalui bentuk ornamentasi dan fraktal serta ukiran bahkan relief menjadi objek dekonstruksi. Distorsi kosmogenik seperti kontradiski, dekomposisi, diskontuintas dan disjungsi menjadi sebuah perenungan baru dalam pennciptaan ruang arsitektur. Hal ini yang dilakukan Yoka Sara dalam prosesnya, ketika dekonstruksi tidak harus terpaku pada tradisi filosofis dan sains barat.

\section{ANALISIS DAN INTEPRETASI DATA}

\section{Pengetahuan Metafisika Lokal}

Konsep metafisika Hindu - Bali, sering dihubungkan dengan segala sesuatu yang berhubungan dengan konsep kosmologi. Seluruh ritual keagamaan di Bali, menggunakan perantara seni yang berupa tarian dan sesajian serta patung maupun sastra bahkan arsitektur termasuk juga pertunjukan. Media kesenian yang fungsinya sebagai mediator antara Tuhan dan manusia, dikenal istilah „Taksu ${ }^{\text {ee }}$ yang menurut kepercayaan lokal dipercaya sebagai pencapain tertingi sebuah karya seni. Taksu berkaitan dengan sebuah kharisma, yakni sebuah aura magis yang dipancarkan oleh suatu karya. Taksu bisa dicapai melalui prosesi ritual, yang sesuai melalui mantra dan sesajian. Mereka percaya, bahwa disetiap objek alam semesta ini memiliki ruh kehidupan yang harus dijaga. Taksu dalam arsitektur, dapat diperoleh melalui implementasi landasan spiritual/ metafisik pembangunan rumah. Beberapa ketentuan filosofis dalam arsitektur tradisional Bali, menurut Gelebet (1986:476) berpegangan pada landasan sebagai berikut.

\section{Landasan filosofis hubungan antara bhuwana alit dan bhuwana agung}

Bhuwana alit adalah badan manusia, yang dihidupkan oleh jiwa atman. Segala sesuatu dalam Bhuwana Alit, ada kesamaan dengan Bhuwana Agung yang dijiwai oleh Hyang Widhi. Kemanunggalan ini, merupakan tujuan hidup manusia.

\section{Landasan etis}

Tata nilai bangunan belandaskan etika, dengan menempatkan bangunan pemujaan/pelinggih di arah hulu dan yang lainnya di hilir. Ini diaplikasikan pada asta kosala kosali 


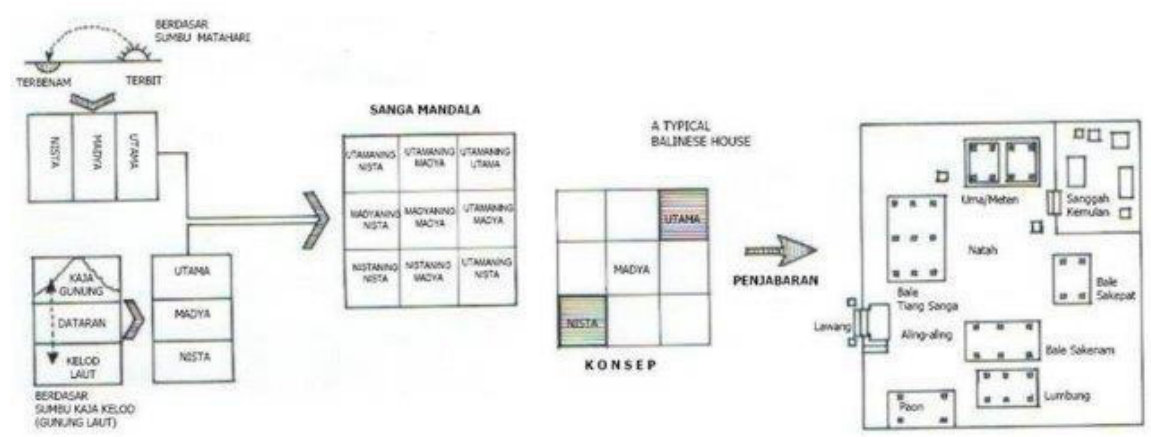

Gambar 1. Konsep mandala-trihita karana pada natah ruang (Sumber: Gelebet. Arsitektur Tradisional Bali, 1986)

tentang pembagian ruang utama, madya dan nista sebagai representasi untuk membina hubungan antara manusia dengan alam semesta.

\section{Landasan ritual}

Prosesi mendirikan rumah, hendaknya dilakukan melalui upacara agama yang bermaksud untuk meminta ijin dan memastikan status tanah (secara metafisik) serta menyucikan maupun menjiwai bahkan memohon perlindungan Hyang Widhi sehingga nantinya terjadi keseimbangan (Taksu).

\section{Landasan tata ruang}

Rwa bhineda, hulu teben dan purusa pradhana.

Rwa Bhineda (dua kontras yang berdampingan), diwujudkan dalam bentuk pertemuan hulu teben/hilir. Hulu adalah arah terbit matahari atau arah gunung dan arah jalan raya. Purusa pradhana melalui penyediaan natar, ruang pertemuan langit dan bumi (courtyard/void).

\section{Tri angga dan tri mandala adalah konsep pembagian ruang.}

Terdiri atas utama, merupakan penempatan bangunan yang bernilai utama (pemujaan). Madya, adalah badan bangunan yang meliputi tiang dan dinding serta kamar maupun ruang aktivitas manusia. Sedangkan nista, adalah bagian terbawah/belakang dan pondasi serta dapur.

\section{Harmonisasi}

Dilakukan melalui penggunaan material potensi setempat dan aplikasi konsep di atas.

Seluruh pengetahuan esensial di atas, dijadikan dasar pembentukan asta kosala kosali. Kitab ini, mengatur pembangunan sebuah rumah secara teknis: proporsi, dimensi dan orientasi. Misalnya, mengenai ukuran tubuh pemilik yang harus sinkron dengan bangunan. Asta bumi adalah pengetahuan tentang cara membaca sebuah bentukan tanah dan cara penyikapan, lalu pangurip, meninggalkan satu bagian tidak selesai (dan hanya undagi saja yang tahu) sebagai wujud paradoks, ketidaksempurnaan yang menjadi sempurna.
Menurut Robert Geldern (1972:2), bahwa aspek metafisik di Asia tenggara (Muangthai, Myanmar, Kamboja, Indonesia) selalu merupakan konsep keseimbangan mikrokosmos dan makrokosmos. Penerapan konsep Mandala di Bali, dilakukan oleh undagi/arsitek. Pada proses penciptaan, Yoka Sara secara teknis tidak mengadaptasi aturan Asta Kosala Kosali namun lebih pada implementasi nilai dasar filosofis/metafisik. Menurutnya, nilai tersebut dapat dicapai melalui bentuk baru sepanjang bentukan tersebut mengikuti esensi dari Asta Kosala Kosali. Bagi Yoka Sara, Asta Kosala Kosali tidak adaptif jika diturunkan pada arsitektur modern saat ini karena dari sisi kebutuhan ruang dan teknologi sudah berkembang pesat serta tidak dapat disamakan dengan konsep fungsi maupun ruang pada arsitektur vernakular. Ia percaya, bahwa esensi sebuah arsitektur nampak pada cara ruang diproduksi. Oleh karena itu, sisi pengetahuan spiritual/metafisik sangat dibutuhkan dalam mengolah sebuah ruang.

Seperti dikatakan oleh Aristoteles, yang dikutip oleh Lorens Bagus pada Kamus Filsafat (1991: 18). Ia mengatakan, bahwa Aristoteles memandang metafisika sebagai dua hal. Pertama, ada sesuatu yang tidak dapat dialami karena berada dalam dunia pengalaman. Sebagai pusat yang terdalam dari dunia pengalaman, yaitu eksistensi universal atau yang tidak dapat ditentukan dan yang menopang setiap serta semua eksisten (sesuatu yang ada). Kedua, ada sesuatu yang tidak dapat dialami karena membatasi dunia pengalaman sebagai dunia terakhir. Bagi seluruh ahli metafisika, kontemplasi ide terhadap "ruang" dan "waktu" adalah tema sentral inkuiri metafisika dalam dunia arsitektur. Penjelajahan terhadap ruang dan waktu merupakan titik perhatian utama peninjauan dalam arsitektur, sehingga tanpa menelusuri/menerjuni metafisika maka arsitektur tidak dapat didefinisikan dengan jelas (Wigley, 1998:17).

\section{Aplikasi Pengetahuan Metafisik Lokal ke dalam Karya Arsitektural}

Setiap berproses, Yoka Sara selalu menganggap bahwa konstelasi ruang itu adalah narasi. Ia melakukan pendekatan story telling, seperti pada sebuah film ataupun teater 


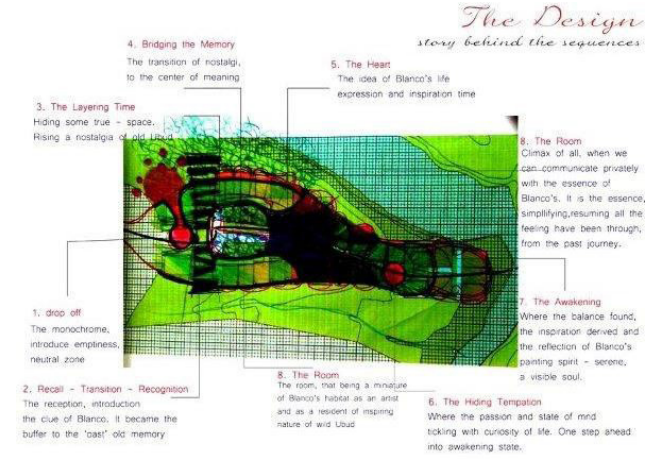

Gambar 2. Hotel Antonio Blanco, Story board ruang (Sumber: Antonio Hotel Proposal Design Dokumentasi Pribadi, 2010)

bahwa ruang adalah representasi sebuah peristiwa sebagai waktu dan tempat selalu mempengaruhi ,,adegan ${ }^{\text {ee }}$ atau aktivitas pengguna secara otomatis. Narasi, selalu berkaitan dengan sebuah ritual dan prosesi memasuki sebuah bangunan. Begitu juga dengan story telling, sebagai hakikatnya Indonesia sangat kental dengan budaya narasinya dan juga menceritakan sesuatu yang merupakan salah satu bentuk eksostensi sebuah pengalaman yang pernah dialami seseorang. Ia ingin menunjukkan unsur pembuka, klimaks, sub klimaks dan unsur penutup pada sebuah ruang dengan menghadirkan elemen surprise, clue serta trailer melalui intensitas berbeda-beda namun masih satu benang merah. Misalnya surprise utama berada pada klimaks dengan memberi efek ,infinitas ${ }^{\text {ee }}$ dan skala gigantis pada suatu pemandangan, kemudian clue hadir pada awal/pembuka ruang seperti car port, hallway, teras dengan memberi sentuhan detail yang membangunkan imajinasi pada ruang berikutnya. Kemudian trailer, biasanya dicapai dengan teknik screen wall tanpa akses yang menunjukkan beberapa ruang di dalam.

Arsitektur, baginya merupakan bahasa. Ruang adalah kata, detail adalah abjad dan kumpulan ruang adalah kalimat. Ia bahkan paham mengenai subjek - predikat objek, pada struktur kalimat. Paham cara menenpatkan geometri, transparansi, solid dan aksen. Pada sebuah kalimat yang menentukan paragraf, tentunya ada sebuah jeda yang membuat sebuah kalimat punya arti. Jeda ini biasanya diinterpretasikan ke dalam ruang sebagai interlude atau bridging, yang membawa kita ke lapisan tema berikutnya. Hal ini, seperti yang dituturkan oleh Simone Pizaggali dalam esainya Space, Poetics and Voids.

Pendekatannya ini, berbasis pada pengalamannya dalam ritual upacara. Upacara di Bali yang sangat terikat prosesi pada tempat dan waktu tertentu. Pada setiap proses, menentukan kelanjutan prosesi berikutnya. Oleh karena itu, ruang adalah esensial. Aplikasinya tentu saja, melalui bangun narasi dari pengetahuan metafisik lokalnya dan imajinasinya membangun cerita. Tidak heran, disetiap akhir proyeknya ia selalu sibuk mencari judul yang tepat. Pada karyanya, Hotel Antonio Blanco, ia menitik beratkan pada

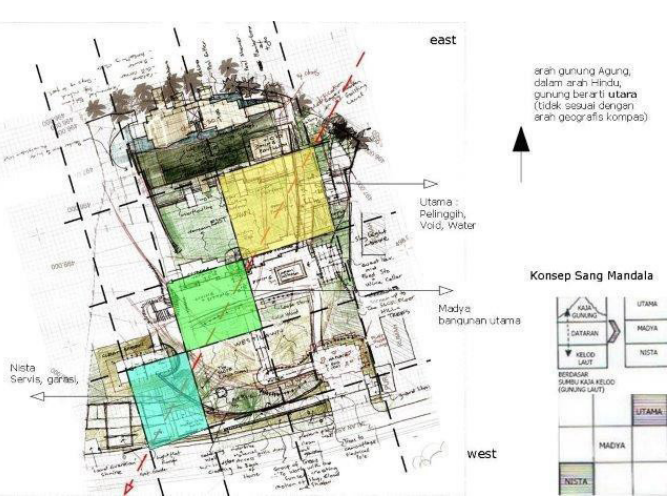

Gambar 3. Konsep Mandala pada Kayu Aga Villa (Sumber: Dokumentasi Pribadi, 2010)

narasi filosofis yang struktur ruangnya bukan hanya sekedar struktur fungsi namun jalinan filosofis dari keseluruhan bahasa bangunan yang penuh metafor.

Acuan yang digunakan dalam menggarap ruang adalah imajinasi cerita, identitk dengan puitik sebuah ruang. Ia mencoba menemukan pembahasaan ruang, dalam aspek emosi yang dialaminya. Pada bagian ini, sering ditemukan aspek surealisnya. Faktor yang diluar prediksi, perkiraan ditemukan pada klimaks ruang. Misalnya pada cerita ruang Hotel Antonio Blanco, ia membagi ruang menjadi ruang masa lalu dan masa kini. Ruang masa lalu (drop off, reception) adalah sebuah bentuk nostalgia keberjayaan Blanco/hall of fame, namun nuansanya monokrom. Ia mereproduksi karya Blanco, dalam nuansa monokrom di resepsionis. Kemudian, ruang ini dijembatani oleh satu area yang disebut dengan "Bridging Memory". Ruang ini, ia manifestasikan sebagai sebuah jembatan disebuah void setinggi delapan meter yang di bawahnya adalah hutan (kumpulan pohon) dan dikelilingin oleh ruang hotel. Ia mencoba menyajikan kesan ubud masa lalu. Hutan, adalah salah satu clue menuju adegan ruang selanjutnya. Sebuah metaphor, bahwa sebenarnya Musem Blanco terkenal dengan area old ubud yang penuh dengan beringin.

Konsep lokal seperti penyatuan langit - bumi (rwa bhineda) ia lakukan dengan pengadaan void, kemudian translasi mandala terlihat dari 3 tahap pembagian ruang depan, tengah dan belakang. Lalu ia memperhatikan juga arah matahari terbit - tenggelam, yang menentukan orientasi massa secara garis besar. Ini terihat pada proses pembuatan villa Kayu Aga, ketika survei tapak tidak jarang Yoka Sara secara intiutif menandai tapak menjadi suatu ruang tertentu yang sesuai dengan pembacaan alamnya. Misalnya, pada bagian tertentu tapak yang unik seperti bagian dekat sungai dan dekat dengan pohon besar ataupun memiliki pemandangan yang cenderung horisontal ditentukan dari living room. Terkadang, fungsi ruang ia imajinasikan dengan ,apa yang sebaiknya terlihat dan tidak terlihat ${ }^{e e}$. Perpustakaan, ia sandingkan pada lantai atas, sebagai pemandangan yang lebih vertikal. Ruang primer, seperti kamar utama dan ruang tengah menempati bagian tapak yang 


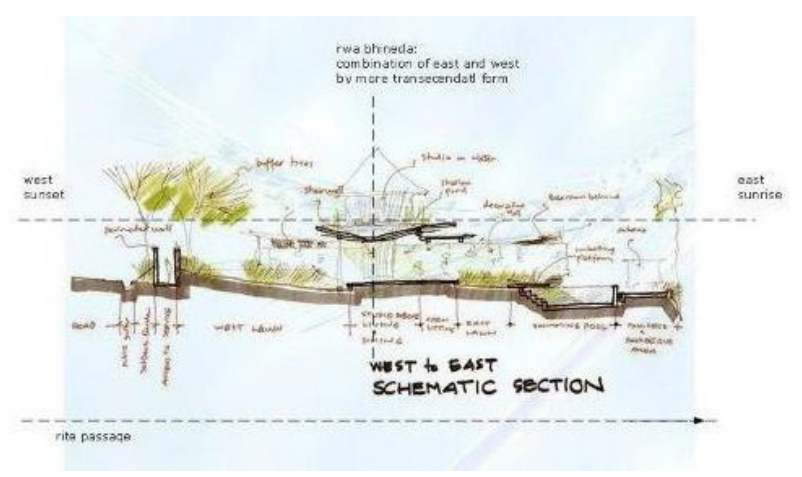

Gambar 4. Potongan Skematik Kayu Aga Villa (Sumber: Dokumentasi Pribadi, 2010)

paling indah.

Pada Villa ini, bila diperhatikan lebih jauh sesngguhnya orientasi massa bangunan timur - barat paling dihindari karena panas matahari. Namun sebaliknya, Yoka Sara justru mengarahkan massa ke timur - barat, sebagai perayaan cahaya. Konsepnya untuk Kayu Aga adalah "a Lot Of Light" perayaan cahaya, permainan bayangan dan konsep perputaran panas melalui buffer lanskap serta jarak spasial bahkan air. Ia tidak ingin memaksakan massanya melawan arahan tapak ke utara - selatan, karena baginya arsitektur merupakan lingkungan tambahan yang melengkapi kekurangan alam bukan melawan alam. Berdasarakan ini, ia percaya bahwa alam yang hidup dapat memberikan timbal balik yang positif pada lingkungan baru tersebut.

Yoka Sara, sangat percaya dengan konsep energi. Filosofi tatanan ruang, sepeti feng shui dan vastu shastra merupakan olah ruang supaya energi disuatu tempat tidak terjebak. Energi merupakan hal yang metafisis, yang biasa dihiraukan. Hanya saja, jika dikaitkan dengan fisika kuantum maka setiap objek (hidup/mati) memancarkan gelombang elektromagnetik (energi). Air, tanah, pasir, angin dan udara merupakan unsur yang memiliki struktur vibrasi dari alam ini yang menghantarkan energi maupun mentransformasi energi menjadi wujud lain (matter). Pada filosofi tata ruang Bali, energi sebenarnya yang memiliki kekuatan metafisik untuk menyatukan manusia dengan alam semesta. Rule of thumbs-nya, dibahasakan dalam asta kosala kosali dan asta bumi atau vastu shastra.

Aplikasi dalam karya arsitekturnya, Yoka Sara selalu mengedepankan aspek energi ini. Ia berpendapat, bahwa suatu tapak yang baik adalah ketika kita merasa nyaman dan betah disana. Sebaliknya, jika kita menemui suatu tempat yang membuat kita tidak betah dan selalu ingin pergi maka berarti ada keterputusan energi terjadi di tapak itu. Ini terbukti dari cara masyarakat di Bali memilih tapak untuk rumah tinggal, pura atau bale. Ada banyak karakterisasi tapak, yang cocok untuk tipologi tertentu sebagai aturan yang terdapat pada asta bumi. Tindak lanjut dari respon tapak ini, dapat dimodifikasi dengan banyak cara. Pada konteks Kayu Aga, bentukan massanya mengikuti

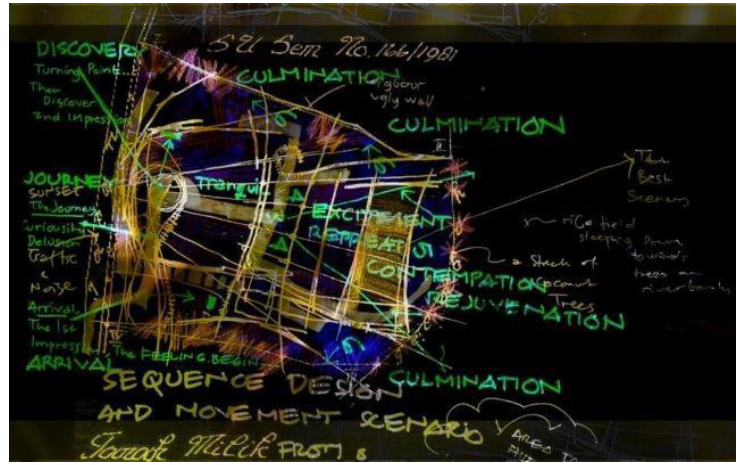

Gambar 5. Story Board sekuens emosi, Kayu Aga Villa (Sumber: Dokumentasi Pribadi, 2010)

bentuk organik tapak yang merespon plastisitas pemandangan. Pemandangan sawah yang cenderung horisontal melalui bingkai bidang yang dinamis, bentuk lengkung yang mampu menangkap sudut pandang lebih banyak.

Narasi ruang ini, tidak dapat terjalin dengan baik tanpa bantuan alam. Oleh Karena itu, dilain pihak ia sangat bebas menentukan gaya pembahasaan. Namun, dilain hal ia sangat konvesional dalam memperhatikan tanda alam. Cahaya, panas dan hujan adalah elemen pembentuk suasana yang tidak perlu dijauhkan dari struktur ruang. Hujan adalah sesuatu yang perlu dialami, karena merupakan pemandangan yang luar biasa. Pada karyanya, White Orchid, ia memasukkan sensasi hujan ke dalam ruang. Ini diwujudkan dengan sebuah open plan, villa ruangan yang mengitari kolam renang tanpa atap. Ruangan beratap datar dan transparan. Ketika hujan, terjadi pengalaman ,water screen $^{\text {ee }}$ pada kaca ruangan. White orchid, konsep villa air yang ,telanjang dan transparan "e namun di sisi lainnya ia punya privasi yang ekstra karena setiap ruangnya berorientasi ke halaman air.

Pada karyanya The Tra Villa, Yoka Sara memberi aksentuasi pada satu pohon beringin di tengah tapak. Pohon beringin tersebut diberi bingkai, seolah ia bagian menerus dari ruang interior dengan teknik gestalt. Bingkai berupa elemen sculptural gigantis, yang berisi water screen. Elemen ini berdiri di tengah kolam renang, seolah ketika kita berenang kita meewati celah sempit yang kemudian menemukan pemandangan yang lebih luas. Villa ini, salah satu villa yang memiliki unsur monumentalitas. Penanda bentuk, menjadi karakter klimaks dari pengalaman ruangnya.

Baginya kualitas arsitektur, apalagi sebuah villa layaknya seperti taman bermain. Villa, adalah bangunan karya seni. Ia harus semaksimal mungkin, membangkitkan daya imajinasi pengguna seperti yang diistilahkan oleh Bachelard "daydream". Ruang imajinatif ini, hanya mampu diciptakan ketika ada asosiasi bentuk yang mengingatkan kita pada memori tersebut. Pohon beringin misalnya, mengingatkan kita pada cerita fairy tale, hocus pocus, magis. Imaji seperti ini, perlu diamplifikasi melalui penyikapan lanskap dan arsitektural terhadap keberadaan alami sebuah 


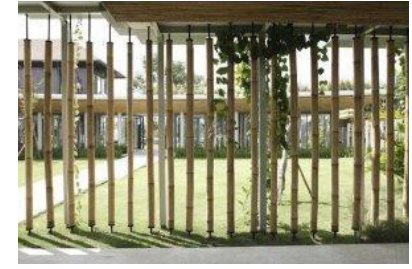

Gambar 6. The „Movie"

Trailer Kayu Aga Villa (Sumber : Dokumentasi Pribadi, 2010)
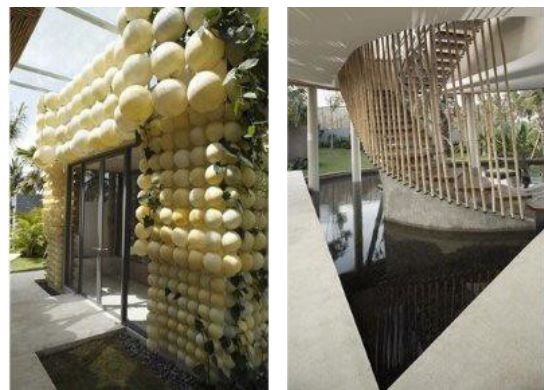

Gambar 7. West Lawn Entrance Kayu Aga Villa (Sumber : Dokumentasi Pribadi, 2010)

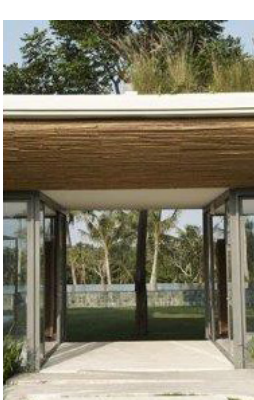

Gambar 8 (kiri) - 9 (tengah) - 10 (kanan). Sculptural cellar, floating stairs, Pohon sebagai penengah vista pintu masuk Kayu Aga Villa (Sumber: Dokumentasi Pribadi, 2010)
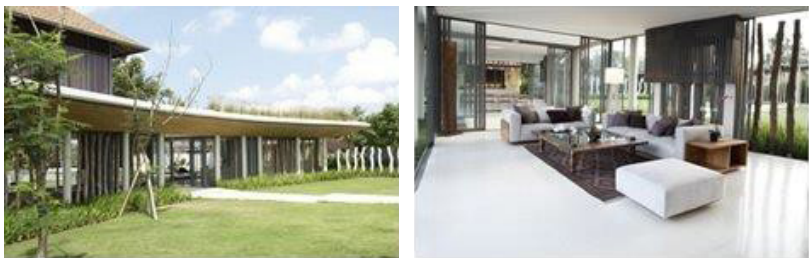

Gambar 11 (kiri) - 12 (kanan). East façade membaur dengan lanskap, a lot of light living room yang transparan, seolah hidup dalam eksterior

(Sumber : Dokumentasi Pribadi, 2010)

alam. Penggarapan elemen alam seperti vegetasi, angin, cahaya, air, bayangan/refleksi bahkan tanah merupakan bagian dari fungsi imajinatif.

\section{SIMPULAN}

Penjelajahan terhadap segala sesuatu yang tidak diketahui/ unknown, dalam pernyataan arsitektur merupakan titik bahasan utama dalam metaforik arsitektur dalam mengembangkan ide sebagai penggugah kreativitas dalam merancang sehingga menghasilkan arstektur yang out of the box.

Arsitektur, baru bermakna apabila bangunan terbangun dan inkuiri metafisik merupakan adjuster. Sebagai katalis untuk dapat menjelajahi ketidakmungkinan, dalam pernyataan arsitektural sebagai sesuatu yang absolut. Hal ini merupakan tantangan besar dalam merancang, pada arsitektur kontemporer. Keberanian mencari hakiki alam semesta, menuju transendensial begitu juga membaurkan pengetahuan lokal yang sifatnya spiritual membuat arsitek bijaksana dalam mempertimbangkan unsur desain bangu-
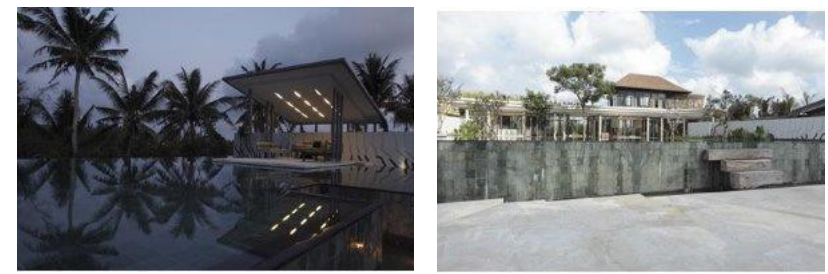

Gambar 13 (kiri) - 14 (kanan). Pool Climax sebagai konsep infinitas (tak terbatas), Flash Back dari arah kolam renang. Kayu Aga (Sumber: Dokumentasi Pribadi, 2010)

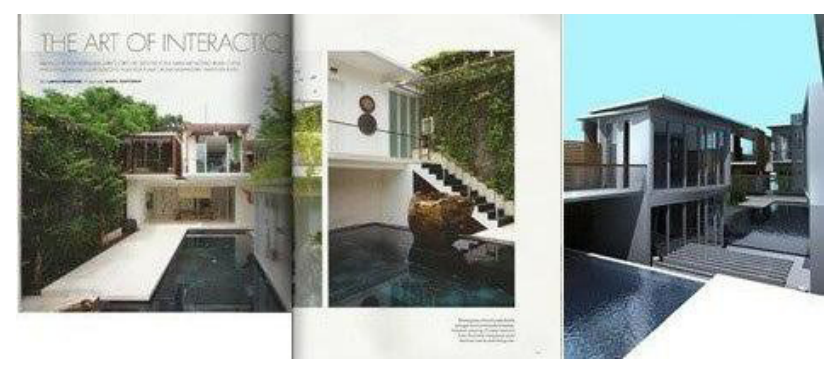

Gambar 15. White Orchid, water levelling sebagai kolam renang, dan penagkap hujan. A Scenery of water stream (Sumber: The Art of Interaction, Elle Magazine, 2011)
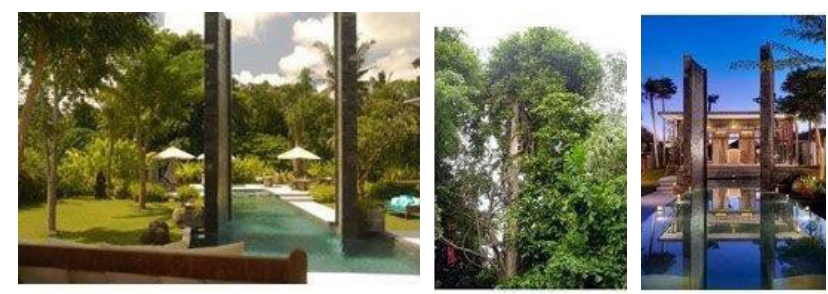

Gambar 16 (kiri) - 18 (kanan). Membingkai pohon beringin (saat pengambilan foto, pohon sudah jatuh karena petir), pohon beringin, tampak villa dari ujung. (Sumber: Dokumentasi pribadi, 2010)

nan sehingga melalui pemahaman ini bangunan kontemporer memiliki sisi keberlanjutan secara psikis dan psikologis. Begitu juga dalam praktek profesi arstektur, yang tidak selalu berkiblat pada sejarah dan metodoogi barat. Indonesia yang kaya dengan ilmu lokalnya, memiliki cara pandang unik dalam hal konten dan teknis yang terbukti pada kelanggengan arsitektur vernakulernya yang timeless.

Pencarian semacam ini, jika dilakukan secara kontinyu dapat membuka wawasan arsitek lebih luas terutama metode mengolah kepekaan rasa. Inspirasi pada akhirnya tidak hanya sebatas refrensi arsitektur, namun juga pada refrensi disiplin ilmu lainnya seperti budaya dan seni serta film maupun teater bahkan juga fashion. Kesegaran metafor, merupakan kualitas baru dalam bahasa arsitektur. Pengalaman ruang, sebagai teks baru pada aspek penyadaran personal. Melalui prinsip ini, maka arsitektur sebagai ilmu mengalami pengkayaan dimensi selain bersifat fungsionalis juga sebagai katarsis pengalaman batin. 


\section{DAFTAR RUJUKAN}

Antoniades, A. C. (1990), Poetics of Architecture. New York: Van Nostrandt Reinhold.

Bachelard, Gaston. (1992). Poetics of Space. New York: Beacon Pres.

Bagus, Loren. (1991). Metafisika. Jakarta: Gramedia.

Comaroff, Joshua and Ong Ker-Shing. (2013). Horror in Architecture. Singapore: ORO editions.

Gelden, Robert Heine. (1972). Konsepsi tentangnegara dan kedudukan raja de Asia Tenggara. Rajawali,

Gelebet, Nyoman. (1986), Arsitektur Tradisional Bali. Jakarta: Proyek Inventarisasi dan Dokumentasi Kebudayaan Denpasar Bali.

Michel Foucault. (1967). Of Other Spaces, Heterotopias. French Journal Architecture/Mouvement/ Continuité in October 1984.

Jenks, Charles. (1995). Architecture of The Jumping Universe. Britain: Academy editions.

Pizzagalli, Simone. (2009). Essay "Space and Voids". Netherland: Architecture and Natura Press.

Sara, Yoka (2010). Antonio Blanco"s Hotel Design Proposal. Denpasar: Yoka Sara International.

Watkin, D. (1977). Morality and Architecture. Oxford: Clarendon Press.

Wigley, Mark. (1995). The Architeture of Deconstrucion: Derrida's Haunt. Massachusets: The MIT Press.

Vidler, Anthony. (2002). Warped Space. Massachusets: The MIT Press. 